\title{
MEDIATION IN DIFFERENT AREAS OF CHINESE LEGAL REALITY - PARAMETRISATION OF SELECTED TERMINOLOGY
}

\begin{abstract}
The paper deals with terminological issues in legal translation. The author has researched the process of establishing equivalents for partially equivalent terminology, using the parametrical approach to legal translation. The research consists of the terminological analysis of the texts of mediation regulations formulated in Chinese and Polish. The objective was to establish translational equivalents in the case of significant differences between the legal systems of the above mentioned linguistic area. The research was financed from the research grant no. 2012/07/E/HS2/00678, titled: Parameterisation of legilinguistic translatology in the scope of civil law and civil procedure awarded by the National Science Centre of the Republic of Poland (Sonata Bis program).

Determining the acceptability of functional equivalents in the selected linguistic area is possible by comparison of their semantics with the legal structure in different legal systems and cultures. The author investigates if attributing properties from dimensions relevant in translation to mediation law terms can be helpful in the process of translation.

Keywords: legal Chinese, legal terminology, mediation in China, legal translation
\end{abstract}

\section{Introduction}

One of the suggested ways of determining equivalents in legal translation involves parameterisation of legal terminology (see: Bańczerowski, Matulewska 2012, Matulewska 2013). This article is written to verify the usefulness of parameterisation in the process of determining equivalents of selected terms concerning mediation occurring in various areas of Chinese legal reality. The term 'Chinese' will only be used in this paper to refer to the mediation terminology used in the People's Republic of China.

The author made a reference to the Chinese-Polish translation commenting on the conducted research. The research corpora encompassed four statutory instruments and one regulation, being in force in People's Repub- 
lic of China titled the People's Mediation Law, the Civil Procedure Law, the Administration Law, the Measures of Using Administrative Mediation to Resolve Contract Disputes and being in force in Republic of Poland in the Civil Procedure Law. The author's analysis refers to the research, which is being conducted currently within the framework of the research grant ${ }^{1}$ ti- $^{-}$ tled: Parameterisation of legilinguistic translatology in the scope of civil law and civil procedure.

\section{Legal term in various areas of application of the legal institution to which it refers}

The language of the law is characterised in particular by the legal terminology, which causes it to be treated as a language with a specific vocabulary. The role of the terms is to ensure clarity of the language of the law. In the view of Jopek-Bosiacka (2006: 30) basically one equivalent should be consistently selected to match one source term. Clarity is actually one of the features of the language of the law, which is continuously emphasised.

The term should not be confused with the concept defined by Mattila (2006: 108), who paraphrased the words of Lauren (1993), as a mental representation of an object as it contains an abstract image created by the human mind on the basis of the attributes typical of a given thing or issue, whereas the term is a technical designator of the concept, its image. It is defined as a verbal expression of a concept being part of a conceptual language system used for particular purposes. The legal concept is intended, according to Weisflog $(1996: 84,91)$ for categorisation and is an abstraction of its kind, which is defined in a given legal system. Legal terms are therefore created in reference to certain legal systems. Differences in terminology concerning seemingly identical legal institutions stem from legal cultures and circumstances in which they appear (see: Cao 2007: 21; Šaračević 2000: 244; Sandrini 1996). Pondering the above considerations it should be highlighted that the area of application of a given legal institution is vital in the process of determining the equivalents of legal terms.

\section{The institution of mediation in translation}

The Chinese language translator may be faced with a substantial challenge in the case of translating texts or interpreting a speech concerning the institution of mediation. This alternative dispute resolution mode is relatively informal as there are no legal standards concerning mediation as 
opposed to the rigid rules of court actions. The established legal standards define only the essential rules of mediation. The translator and/or researcher of the mediation language acquires information about its terminology or phraseology from the legal regulations only to a certain extent, but most of his or her knowledge is derived from learning by practical experience or from a few specimen documents.

Although legal Chinese is strongly influenced by the Western legal systems, the language of alternative dispute resolution depends on communicative purposes and genre expectations, as well as on issues of politeness, required levels of indirectness and face saving (see: Zhu 1999; Zhu 2005; Zhao, Zhang 2012).

As all kinds of relations may lead to a conflict the means and specificity of dispute resolution in China should be considered for a proper understanding of the legal concepts to which the analysed terms refer to. Becoming familiar with the Chinese legal concepts and legal culture affecting the behaviour of the Chinese people during their cooperation with Western partners is currently indispensible. Irrespective of the type of the activity business or scientific, or practically any kind of activity - one needs to know the Chinese culture if one wishes to follow the Chinese line of thinking.

During dispute resolution in the mediation process a third party, who is unbiased and impartial with respect to the parties and their conflict, namely a mediator acts as intermediary in the process of reaching an agreement and concluding the settlement by the parties (Zedler 2009: 22; Sheng 2012: 5; Guo 2013: 9).

The mediator's task is to monitor the course of the talks and eliminate any discrepancies between the stands taken by the parties and eliminate any communication barriers. He should also evaluate any chances for dispute resolution and supervise practical implementation of the solutions accepted by the parties. The general concept of mediation in the legal sense matches its colloquial definition, as it means acting as intermediary in a conflict (Zedler 2009: 11).

Informal dispute resolution is intended to facilitate a peaceful conversation between the parties about the differences between them. Mediation (except for court mediation) may be conducted for an indefinite period of time in the offices of a legal practice, a hired conference room, a private flat or in a cafe. Moreover, mediation is voluntary (see: S. 183 of Polish Civil Procedure Law; Guo 2013: 13-14). Each party takes his/her own decision to participate in mediation and this decision cannot be imposed either by a court or the other party. This means that each party may at any time withdraw from mediation. These two features of mediation: informality and 
voluntariness have the effect that the mediation procedure and, as a result, the language of mediation are not fully predictable. One can of course determine the recurring terminology or phraseology but it is not easy to determine and select fixed phrases used in the mediation process as opposed to the court procedure, whose linguistic aspect has been described by linguists and translators/interpreters).

\section{Mediation in various areas of legal reality}

In the Polish legal doctrine there are two basic forms of mediation, namely:

i. institutional mediation;

ii. ad hoc mediation.

Institutional mediation is conducted by a specific mediation centre and is often initiated by the court (Pazdan 2004: 14). In case of ad hoc mediation the parties appoint the mediator or the mediation team for a given case (Zienkiewicz 2007: 49).

In the Chinese legal doctrine there are three separate mediation systems, namely:

i. national court mediation (mediation in the court proceedings),

ii. people's mediation,

iii. administrative mediation,

and two other types of mediation, namely:

iv. institutional mediation conducted by specific mediation centres,

v. mediation as a part of arbitration proceedings (Kaufmann-Koller \& Fan 2008: 159, Sheng 2012: 6-7).

The procedure of national court mediation, people's mediation and administrative mediation follows the law and policy of the state. The differences described in the literature devoted to this subject involve differences with respect to: the body conducting mediation, the scope of mediation and the effects of mediation (Zhang 2007: 985). Their diversity results from the long and complex history of China and the state policy.

The national court mediation, namely mediation in the court proceedings (in Chinese 法院调解 făyuàn tiáojiĕ, 诉讼内调解 sùsòng nèi tiáojiĕ) is conducted to settle civil, commercial and private criminal disputes. It encompasses the greatest number of potential disputes (Zhang 2007: 987). It consists of conducting mediation during courtroom interrogations provided that the parties agree to it. Exceptions include divorce cases where mediation is a normal element of the proceedings. If the parties to the dispute can- 
not reach agreement or if one party withdraws from signing the settlement, the case is referred to the court for continuation (S. 91 of Chinese Civil Procedure Law, Grzybek 2013: 116). The national court (in Chinese 人民法院 rénmín făyuàn) is the body supervising the national court mediation.

People's meditation (in Chinese 人民调解 rénmin tiáojiě) in turn is intended to resolve civil disputes and applies to a narrower scope of cases but in contrast settles the greatest number of disputes as such disputes most often arise in social relations (Zhang 2007: 987). It is conducted by People's Mediation Committees (in Chinese 人民调解委员会 rénmín tiáojiě wěiyuánhui) and originates from the tools of the Communist Party of China and the system in which the people implement self-education and selfdiscipline (Zhang 2007: 995; Sheng 2012: 7). The people's mediation committees are set up in municipal committees of residents (in Chinese 居民委员会 jūmin wěiyuánhui) and in rural committees (in Chinese 村民委员会 cūnmín wěiyuánhui) (Sheng 2012: 7-8). Business entities and institutions may also set up people's mediation committees provided that they shall serve the people to settle civil disputes (Zhang 2007: 996-997). The people's mediation system, as a legal system supporting factor, is a type of so-called people's democratic self-government. Section 111 of the Constitution of People's Republic of China enables the residents of rural areas and committees of rural residents to establish mediation committees, which will manage settling the disputes arising between them.

Administrative mediation (in Chinese 行政调解 xíngzhèng tiáojiě) is conducted by state administration units at two levels: by people's governments or by state administration bodies (Sheng 2012: 6). It is applied in civil, commercial and certain criminal disputes but in only those cases, which are defined in relevant legal regulations (Zhang 2007: 987). For example administrative organs for industry and commerce have the authority to mediate in the disputes arising from contracts (art. 6 of the Measures of Using Administrative Mediation to Resolve Contractual Disputes, Fan 2013: 161). This mediation is voluntary and if one party refuses mediation, a given administrative body cannot conduct it (Zhang 2007: 987-989, Fan 2013: 161 in Grzybek 2013: 118).

\section{Parameterisation}

Parameterisation is applied for the systematic description of reality (see: the method of axiomatisation of the legal linguistic reality - Bogusławski 1986, Bańczerowski \& Matulewska 2012, Matulewska 2013). In order to 
thus describe the reality, relevant parameters of a given component of reality need to be determined. Such objects of legal reality may include legal terms. According to Matulewska (2013: 107) who also calls the mentioned parameters dimensions, each parameter is a set of homogenous properties, which indicates that the properties are of the same type and therefore are comparable and simultaneously mutually exclusive - thus the object may assume only one property from each dimension. Pursuant to the parameterisation theory, each dimension is a collection of properties, which may be assumed by a described object of reality. There are dimensions presented in respect of semantic, systemic and genre-related relations, i.e.: lect, text genre, branch of law to which the text refers, the time of source text creation, the language of the source text, source-text legal reality, source text language variety, semantic relations (e.g. relation of synonymy, relation of polysemy or homonymity, relation of hyperonymy), systemic relations e.g. common law - civil law, etc. The choice of the proper equivalent of a term shall be more suitable if one defines whether / with respect to which parameters the compared terms differ, namely which of their features are different.

Subsequent sections of this article show a selected part of parameterisation results concerning the terms meaning settlement concluded before a mediator in the reality of the Chinese legal language and Polish legal language. Parameterisation research was accompanied by other methods of studying legal terminology, namely:

i. the comparison of parallel texts (see: Neubert 1996, Delisle et al. 1999, Lewandowska-Tomaszczyk 2005, Kubacki 2013),

ii. the analysis of comparable texts (see: Neubert 1996, Delisle et al. 1999, Lewandowska-Tomaszczyk 2005),

iii. the concept of adjusting the target text to the communicative needs and requirements of the community of recipients (see: Vermeer 2001, Šarčević 2000, Kierzkowska 2002, Matulewska 2007).

\section{Parameterisation of the Chinese term 调解协议 tiáojiĕ xiéyi}

The mediation, the terminology of which was analysed by the author of the paper, is intended to conclude a settlement before a mediator, namely settlement during mediation (调解协议 tiáojiě xiéyi). Exceptions to this include divorce cases where the mediation is intended to reconcile the parties (Błaszczak, Ludwik 2007: 34). 


\section{Settlement concluded before a mediator in the Polish legal system}

Concluding the settlement the parties make concessions to each other with respect to the legal relationship between them in order to eliminate any uncertainty of the claims recoverable there under or to ensure their enforceability or to settle the dispute already existing or likely to arise (S. 917 of Polish Civil Code).

Settlement defined in the legal literature as a court settlement, which, as emphasised by Czachórski (2007: 608) is concluded in front of a judicial body in order to avoid or terminate the dispute, constitutes a separate institution of the procedural law. The concept of this settlement deviates from the concept of the settlement as construed under the provisions of the Civil Code although it may involve also a settlement in the meaning of the substantive law. Pursuant to S. 10 of the Civil Procedure Code in cases where concluding a settlement is permitted the court should at each stage of the proceedings strive to settle the disputes amicably; in such cases the parties may also conclude a settlement before a mediator (Staszczyk 2013: 99). In S. 18312 of the Civil Procedure Code the issue of settlement concluded before a mediator is separately discussed and there it is referred to as 'settlement concluded before a mediator'. In the Polish law the settlement concluded before the court has a procedural nature, namely it is concluded by the parties and terminates the dispute. Moreover, in the light of S. 917 of the Civil Code it has a legal-substantive nature and due to S. $777 \S 1$ (1) of the Civil Procedure Code it is an enforcement order.

\section{Settlement concluded in front of a mediator in the Chinese legal system}

Previously mentioned different types of mediation used in the legal reality of the Peoples' Republic of China, although regulated by other legal acts, are defined and described with the use of almost identical terminology. Each of those mediation processes is intended to reach agreement and conclude a settlement proving the end of the dispute. The settlement concluded before the mediator in each of the abovementioned mediation procedures has the same name, i.e. 调解协议 tiáojiě xiéyi. However, should the Chinese term “调解协议' be in each case and, in particular, for each recipient of the target text translated as "the settlement concluded before a mediator" (Polish: 'ugoda zawarta przed mediatorem')? This question may be answered due 
to the parameterisation of the Chinese word '调解协议' and the Polish term "settlement concluded before a mediator".

In the scope of procedural mediation (诉讼调解 sùsòng tiáojiĕ) the settlement signed by the parties (in Chinese 调解协议 tiáojiě xiéyi) has the legal effects of a court judgment whose content is binding on both parties. Consequently, if one of the parties to the dispute attempts to withdraw from it, the other party may petition the court to have the provisions of the settlement performed under enforcement proceedings. The parties to the dispute in this case may not file a new petition in the same case or appeal against the settlement reached during the mediation.

However, the settlement resulting from people's mediation (人民调解 rénmín tiáojiě) and administrative mediation has no legal effects. Basically the parties must perform the settlement provisions but the settlement itself has no direct legal effects as in the case of the National Court mediation (Zhang 2007: 997). If one of the parties to the dispute refuses to perform the provisions included in the settlement, the other party may only petition the court to issue a settlement performance order. If one of the parties to the dispute or both parties withdraw from the settlement, then they may file a petition with the court (Zhang 2007: 987-989).

Table 1

Parameterisation of the term 调解协议 tiáojiě xiéyi

\begin{tabular}{|c|c|c|c|c|c|}
\hline & $\begin{array}{c}\text { term } \\
\text { dimension }\end{array}$ & 调解协议 & 调解协议 & 调解协议 & $\begin{array}{c}\text { ugoda zawarta } \\
\text { przed mediatorem }\end{array}$ \\
\hline 1. & $\begin{array}{l}\text { the author } \\
\text { of the text }\end{array}$ & legislator & legislator & legislator & legislator \\
\hline 2. & $\begin{array}{l}\text { text delivery } \\
\text { form }\end{array}$ & written & written & written & written \\
\hline 3. & text status & binding & binding & binding & binding \\
\hline 4. & $\begin{array}{l}\text { the time of } \\
\text { text creation }\end{array}$ & valid & valid & valid & valid \\
\hline 5. & $\begin{array}{l}\text { branch of } \\
\text { law to which } \\
\text { the text } \\
\text { refers to }\end{array}$ & $\begin{array}{l}\text { civil procedure } \\
\text { law }\end{array}$ & mediation law & $\begin{array}{l}\text { administrative } \\
\text { law }\end{array}$ & $\begin{array}{l}\text { civil procedure } \\
\text { law }\end{array}$ \\
\hline 6. & text genre & a statute & a statute & $\begin{array}{l}\text { administrative } \\
\text { regulations }\end{array}$ & a statute \\
\hline 7. & $\begin{array}{l}\text { the language } \\
\text { of the text }\end{array}$ & Chinese & Chinese & Chinese & Polish \\
\hline
\end{tabular}




\begin{tabular}{|l|l|l|l|l|l|}
\hline 8. & $\begin{array}{l}\text { meaning of } \\
\text { the term }\end{array}$ & $\begin{array}{l}\text { in scope of le- } \\
\text { gal effect: agree- } \\
\text { ment (equal le- } \\
\text { gal effect with } \\
\text { judgments) }\end{array}$ & $\begin{array}{l}\text { in scope of legal } \\
\text { effect: no legal } \\
\text { effect (performed } \\
\text { on the parties' } \\
\text { own initiative) }\end{array}$ & $\begin{array}{l}\text { in scope of legal } \\
\text { effect: no legal } \\
\text { effect (performed } \\
\text { by the parties' } \\
\text { own initiative) }\end{array}$ & $\begin{array}{l}\text { in scope of legal } \\
\text { effect: an en- } \\
\text { forcement order } \\
\text { after approval of } \\
\text { a court }\end{array}$ \\
\hline
\end{tabular}

As far as the dimension 8 has four parameters/properties, all four terms assume different properties (are complementary in respect to dimension 8). The relation of convergence holds between the terms in question in respect of dimensions 1-4. The complimentary relation holds in respect of dimensions $5-7$. The relation of divergence holds between three Chinese terms and the Polish one in respect to dimension 8.

Considering the said description of different types of settlement concluded before a mediator in the Chinese legal reality, one may identify the pertinent semantic relation from the perspective of translation of terminological units: the relation of polysemy.

Table 2

The semantic relation of polysemy at the intralingual level (for the Chinese language)

\begin{tabular}{|l|l|l|}
\hline Legal system reality & polysemes & $\begin{array}{l}\text { Dimensions in respect of which the terms assume } \\
\text { different properties }\end{array}$ \\
\hline $\begin{array}{l}\text { the law of People's } \\
\text { Republic of China }\end{array}$ & 调解协议 & $\begin{array}{l}\text { branch of law to which the text refers: } \\
\text { civil procedure law }\end{array}$ \\
\cline { 2 - 3 } & 调解协议 & $\begin{array}{l}\text { branch of law to which the text refers: } \\
\text { law of People's mediation }\end{array}$ \\
\cline { 2 - 3 } & 调解协议 & $\begin{array}{l}\text { branch of law to which the text refers: } \\
\text { administrative law }\end{array}$ \\
\hline
\end{tabular}

Table 2 shows the semantic relation of polysemy at the intra-lingual level for the Chinese language. The term 调解协议 applies to different branches of law, within which it is crucial to distinguish its scope of meaning. The polysemes differ in respect to the dimensions of branch of law to which the text refers. Depending on the given branch of law to which the term 调解协议 refers, the Chinese settlement concluded before a mediator has different features, which shall be more or less relevant for the close recipient or the distant recipient of one's translation. The branch of law to which the settlement relates determines its legal effects. 


\section{Concluding remarks}

On the basis of the presented fraction of research into the terminology of mediation as a means of settling disputes, it may be concluded that parameterisation of legal terminology may be useful in legal translation. Application of this method is particularly justified if semantic relations occur between the equivalents, in particular in the case of interlingual polisemy, which occurs in the Chinese legal language despite postulates of clarity of legal language and the language of law. Intralingual polisemy requires special analysis in particular if the translation is directed at close recipients.

Mediation in the Polish legal culture and the Chinese legal culture constitute two separate institutions derived from different historic backgrounds and affected by different political, social and cultural factors. The Chinese term 调解协议 tiáojiě xiéyi is the technical designation of different concepts representing different mental representation of settlement based on the different attributes.

The distant recipient of the Polish translation of the text containing the term 'settlement' may be unaware of the fact that the settlement resulting from mediation procedure regulated by 'the people's mediation committee' shall not have the same legal effect as the settlement concluded before a mediator during the proceedings in the national court. And the people's mediation, unknown in the legal culture of western countries, should not be underestimated. Although this mediation type was not formally established until 1954, the statistical data of 2010 reveal that there were 4,900,000 mediators in China working in over 800,000 people's mediation committees on solving 54 per cent of civil disputes (Fan 2013: 160).

\section{N O T E}

1 The research grant no. 2012/07/E/HS2/00678, titled: Parameterisation of legilinguistic translatology in the scope of civil law and civil procedure awarded by the National Science Centre of the Republic of Poland (Sonata Bis program).

\section{R E F E R E N C E S}

Bańczerowski, J. \& Matulewska, A. (2012). Towards the Foundations of Legilinguistic Translatology. In P. Grzegorczyk, K. Knoppek \& M. Walasik (eds.), Proces cywilny. Nauka-Kodyfikacja-Praktyka. Ksiega jubileuszowa dedykowana Profesorowi Feliksowi Zedlerowi (pp. 1225-1261). Warszawa: Wolters Kluwer Polska. 
Bańczerowski, J. (2001). The Linguistic Legacy of Ludwik Zabrocki. In St. Puppel (ed.), The Ludwik Zabrocki Memorial Lecture (pp. 9-49). Poznań: Adam Mickiewicz University.

Błaszczak Ł., Ludwik M. (2007). Sadownictwo polubowne (arbitraż). Warszawa: C.H. Beck.

Cao, D. (2007). Translating Law. Clevedon: Multilingual Matters Ltd.

Czachórski W. (2007). Zobowiazania. Zarys wykładu. Warszawa: Wydawnictwo Lexis Nexis.

Delisle, J. et al. (eds.) (1999). Translation Terminology. Amsterdam/Philadephia: John Benjamins Publishing Company.

Fan, K. (2013). Arbitration in China. A Legal and Cultural Analysis. Portland: Hart Publishing.

Grzybek, J. (2013). Alternatywne metody rozwiazywania sporów w przekładzie chińskop̄olskim i polskoc̄hińskim. Studium badawcze terminologii z zakresu arbitrażu. Poznań: Wydawnictwo Naukowe Contact.

Guo, X. (2013). 民事诉讼调解新论 [Minshi susong tiaojie xinlun]. 北京: 中國政法大學 出版社.

Jopek-Bosiacka, A. (2006). Przekład prawny i sadowy. Warszawa: Wydawnictwo Naukowe PWN.

Kaufmann-Kohler G., Fan K. (2008). Integrating Mediation into Arbitration: Why It Works in China? In Journal of International Arbitration 4.

Kierzkowska, D. (2002). Ttumaczenie prawnicze. Warszawa: Wydawnictwo TEPIS.

Kubacki, A. D. (2012). Tłumaczenie poświadczone. Status, ksztatcenie, warsztat $i$ odpowiedzialność tlumacza przysiegłego. Warszawa: Wolters Kluwer Business.

Kubacki, A. D. (2013). Teksty paralelne jako narzędzie pomocnicze przy sporządzaniu tłumaczeń specjalistycznych. Comparative Legilinguistics 20013/13, $137-148$.

Lewandowska-Tomaszczyk, B. (ed.) (2005). Podstawy jezykoznawstwa komputerowego. Łódź: Wydawnictwo Uniwersytetu Łódzkiego.

Mattila, H. (2006). Comparative Legal Linguistics. England: Ashgate.

Matulewska, A. (2007). Lingua Legis in Translation. Frankfurt am Main, Germany: Peter Lang Publishing House.

Matulewska, A. (2013). Legilinguistic Translatology. A Parametric Approach to Legal Translation. Frankfurt am Main, Germany: Peter Lang Publishing House.

Neubert, A. (1996). Textlinguistics of Translation: The Textual Approach to Translation. In R. M. Gaddis (ed.), Translation Horizons Beyond the Boundaries of Translation Spectrum. Translation Perspectives IX (pp. 87-105). Binghamton: Center for Research in Translation.

Newmark, P. (1982). Approaches to Translation. Oxford: Pergamon Press Ltd. 
Newmark, P. (1988). A Textbook of Translation. UK: Prentice Hall International Ltd.

Newmark, P. (1991). About Translation. Clevedon: Multilingual Matters Ltd.

Pazdan, M. (2004). O mediacji i projekcie jej unormowania w Polsce. In Rejent $2006 \mathrm{nr} 4$ (pp. 9-23).

Šarčević, S. (2000). New Approach to Legal Translation. The Hague: Kluwer Law International.

Sandrini, P. (1996). Terminologiearbeit im Recht. Deskriptiver begriffsorientierter Ansatz vom Standpunkt des Übersetzers. IITF-Series 8. Vienna: TermNet.

Sheng, Y. (ed.) (2012). 人民调解实务 [Renmin tiaojie shiwu]. 北京: 中国政法大学出版社.

Weisflog, W. E. (1996). Rechtsvergleichung und juristische Übersetzung. Eine interdisziplinäre Studie. Zürich: Schulthess Polygraphischer Verlag.

Vermeer, H. J. (2001). Skopos and Commission in Translational Action. In L. Venuti \& M. Baker (eds.), The Translation Studies Reader (pp. 221-232). London, New York: Routlege.

Vinay, J.-P., Darbelnet J. (1966). Stylistique comparée du français et de l'anglais. Paris: Didier.

Zabrocki, L. (1963). Wspólnoty komunikatywne w genezie i rozwoju języka niemieckiego. Część I. Prehistoria języka niemieckiego. Wrocław, Warszawa, Kraków: Zakład Narodowy imienia Ossolińskich Wydawnictwo Polskiej Akademii Nauk.

Zedler, F. (2009). Mediacja w sprawach cywilnych. In Czura-Kalinowska D. (ed.),

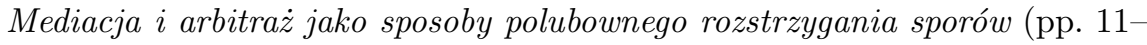
26). Poznań: Wydawnictwo Wyższej Szkoły Pedagogiki i Administracji.

Zhang, B. (张柏峰) (red.). (2007). 中国当代司法制度 [Zhongguo dangdai sifa zhidu]. 北京: 法律出版社.

Zhu, Y. (2005). Written Communication cross Cultures. Amsterdam: John Benjamins.

Zhu, Y. (1999). Business Communication in China. New York: Nova Science Publishers.

Zhao, X., Zhang, Q. (2012). Negotiating with Vague Language: A Chinese Perspective. Beijing: China Social Science Press.

Zienkiewicz, A. (2007). Studium mediacji. Od teorii ku praktyce, Warszawa: Wydawnictwo Difin.

\section{Source Texts}

Polish Code of Civil Procedure - Ustawa z dnia 17 listopada 1964 r. - Kodeks postępowania cywilnego (Dz.U. nr 43, poz. 296 z późn. zm.).

Mediation Law of the People's Republic of China of $28^{\text {th }} 082010$ - in Chinese 中华人民共和国调解法

Civil Procedure Law of the People's Republic of China of $09^{\text {th }} 041999$ - in Chinese 中华人民共和国民事诉讼法 